\title{
AKRAN ZORBALIĞI
}

\author{
TUNA ÇAK ESEN
}

Hacettepe Üniversitesi, Çocuk ve Ergen Ruh Sağlı̆ı ve Hastalıkları Anabilim Dalı, Ankara, Türkiye

Son yıllarda, giderek artan veri hacmi, akran zorbalığının yüz milyonlarca çocuğu ve ergeni etkilediğini ve olumsuz psikiyatrik sonuçların erişkinliğge dek sürebildiğini göstermektedir (1). Alan yazının da her üç çocuktan birinin akran zorbalığı ile karşılaştığı, ve çocuk ve ergenlerin \% 10-15'nin altı aydan fazla süren "kronik" zorbalığa maruz kaldığı bildirilmektedir (2). Gerek sıklığı gerek ise uzun dönem olumsuz etkileri nedeniyle günümüzde akran zorbalığı Dünya Sağlık Örgütü ve Birleșmiş Milletler tarafından küresel bir sağlık sorunu olarak kabul edilmektedir $(3,4)$.

Yakın zamanda Moleküler Psikiyatri dergisinde yayınlanan önemli bir çalışmada ise uluslararası bir ekip tarafından toplanan boylamsal beyin manyetik rezonans görüntüleme verilerine göre, ergenlik döneminde kronik zorbalığa maruz kalmanın normal beyin gelişiminde hacimsel sapmalarla ilişkili olduğu gösterilmiştir (5). Bu çalısmada kronik zorbalığa maruz kalan ergenlerde yıllar içinde belirlenen kaudat ve putamen bölgelerinde belirginleşen bu hacim azalmaları maalesef ki çocuk ergen psikiyatristlerine erken çocukluk döneminde ihmal ya da istismar yaşayan çocuklarda görüldüğü bilinen yapısal beyin değişikliklerini hatıllatmaktadır (6). Bu benzerlik ise akran zorbalığının önlenmesinin gelişimsel açıdan istismar inmalin önlenmesi kadar kritik bir öneme sahip olduğunu göstermektedir.

Türkiye Çocuk Hastalıkları Dergisi'nin bu sayısında yayınlanan Çelen Ç. ve ark. (7) çalışması da bu önemli konuyu incelemektedir. Çalışmada Şubat-Mart 2018 tarihlerini kapsayan 2 ayllk dönemde psikiyatrik yakınma ile başvuran 11-18 yașları arasındaki ergenlerde akran zorbalığı alt tiplerinin sosyodemografik değişkenler, siber zorbalık, siber mağduriyet ve öfke ifade tarzları ile ilişkileri araştırımıştır. En dikkat çekici bulgulardan biri çalışmaya katılan ergenlerin dörtte üçünden fazlasının zorba/mağdur döngüsünün içinde olduklarının belirlenmesidir. Bu oran konuya ilişkin ülkemizde yapılmış olan toplum temelli çalısmalara göre oldukça yüksek ve dikkat çekicidir. Çalışma grubunun toplum örnekleminden farklı olarak psikiyatrik yakınması olan klinik örneklem olması nedeniyle daha yüksek bir oran saptanması beklenir bir bulgudur. Yine de, poliklinikte gördüğümüz her dört ergenden üçünün bu üzücü döngü içinde olması ve kronik akran zorbalığını kalıcı psikiyatrik ve biyolojik etkileri göz önüne alındığında, konunun günlük klinik pratikte çok gündeme gelmiyor olması akran zorbalığına yönelik geliştirimesi gereken duyarlığı işaret etmektedir.

\section{KAYNAKLAR}

1. Sigurdson JF, Undheim AM, Wallander JL ve ark. The long-term effects of being bullied or a bully in adolescence on externalizing and internalizing mental health problems in adulthood. Child Adolesc Psychiatry Ment Health 2015; 9;42. https://doi.org/10.1186/s13034-015-0075-2.

2. Wolke D, Lereya ST. Long-term effects of bullying. Archives of Disease in Childhood 2015;100:879-885.

3. http://www.euro.who.int/_data/assets/pdf_file/0005/303485/HBSC-No.7_factsheet_Bullying.pdf?ua=1

4. http://uis.unesco.org/en/news/new-sdg-4-data-bullying

5. Quinlan EB, Barker ED, Luo Q, Banaschewski T, Bokde ALW, Bromberg U et al. Peer victimization and its impact on adolescent brain development and psychopathology. Mol Psychiatry 2018; https://doi.org/10.1038/s41380-018-0297-9.

6. Teicher M, Samson J, Anderson C, Ohashi K. The effects of childhood maltreatment on brain structure, function and connectivity. Nat Rev Neurosci 2016;17;652-666 https://doi.org/10.1038/nrn.2016.111.

7. Çelen Ç, Çöp E, Şenses Dinç G ve ark. Çocuk Psikiyatrisi Polikliniğine Başvuran Ergenlerde Akran Zorbalığı ile Siber Zorbalık ve Öfke Ifade Tarzlarının İlişkisi. Türkiye Çocuk Hast Derg 2020;14:108-18.

(1] ÇAK ESEN T: 0000-0001-9514-0855 DOI: $10.12956 /$ tchd.704963

Türkiye Çocuk Hast Derg/Turkish J Pediatr Dis / 2020; 4: 101-101 